\title{
Seedling recruitment of perennial grasses in degraded areas of the Patagonian Monte
}

\author{
ALEJANDRO JORGE BISIGATO AND MONICA BEATRIZ BERTILLER
}

Authors are Research Scientists, Centro Nacional Patagónico (CONICET), Boulevard Brown S/N, 9120 Puerto Madryn, Chubut, Argentina.

\begin{abstract}
The recruitment of perennial grass seedlings in degraded areas of the Patagonian Monte was analyzed. Recolonization of large bare-soil areas by dwarf shrubs or perennial grasses was hypothesized to create favorable microsites for grass seedling recruitment. Under natural field conditions, soil moisture $(0-20 \mathrm{~cm})$, root biomass $(0-20 \mathrm{~cm})$, the soil seed bank of perennial grasses, and density of perennial grass seedlings in the center of large bare soil areas and in microsites neighboring isolated plants of perennial grasses and dwarf shrubs were assessed. A manipulative experiment was conducted to evaluate seedling recruitment at the $\mathbf{3}$ microsites with identical density of seed addition of perennial grasses, under situations of root exclusion, and water addition.

Under natural field conditions, root biomass did not differ among microsites. Soil moisture, seed density, and seedling density of perennial grasses were higher near perennial grasses than in bare soil or next to dwarf shrubs. Recruitment of perennial grass seedlings did not differ among microsites when the density of seeds did not vary among them or roots of the established plants were excluded. Water increased perennial grass seedling recruitment at all microsites. In degraded areas of the Patagonian Monte the spatial distribution of the soil seed bank followed by water availability are the main limiting factors of seedling recruitment of perennial grasses. Managerial practices oriented to maintain and increase the soil seed bank of perennial grasses, such as grazing exclusion during the grass reproductive period, might contribute to promote the re-establishment of perennial grasses.
\end{abstract}

Key Words: facilitation, competition, arid ecosystems, soil seed bank, patch dynamics, water availability

Vegetation in desert ecosystems consists of discrete plant patches separated by bare soil areas (Noy-Meir 1973). Processes related to plant patches lead to the accumulation of resources (water, nutrients, organic matter, and seeds) in the soil beneath

This work was partially supported by Consejo Nacional de Investigaciones Científicas y Técnicas (CONICET) of Argentina PICT-99 08-06027 BID 1201/OC-AR of the National Agency for Scientific and Technological Promotion. AJB was supported by a fellowship of CONICET. We thank Gustavo Pagnoni, Fernando Coronato, Claudia Sain, Analía Carrera, and Esteban Kowaljow for their assistance in field and laboratory work. Recognition also is given to Mr. Fermín Sarasa who allowed access to the study area in Estancia San Luis:

Manuscript accepted 29 May 03

\section{Resumen}

Se analizó el reclutamiento de plántulas de pastos perennes en áreas degradadas del Monte Patagónico. Se hipotetizó que la recolonización de las áreas de suelo desnudo por subarbustos o pastos perennes crea micrositios favorables para el reclutamiento de estos últimos. Se analizó, en situaciones de campo, la humedad edáfica $(0-20 \mathrm{~cm})$, la biomasa de raíces $(0-20 \mathrm{~cm})$, el banco de semillas de pastos perennes en el suelo, y la densidad de plántulas de pastos perennes en micrositios vecinos a plantas aisladas de pastos perennes y subarbustos. Igualmente, se condujo un experimento manipulativo con el objeto de evaluar, bajo situaciones de exclusión de raíces y adición de agua, el reclutamiento de plántulas en los tres micrositios con igual densidad de agregado de semillas de pastos perennes.

En situaciones de campo la biomasa de raíces no difirió entre micrositios. La humedad edáfica, la densidad de semillas, y la densidad de plántulas de pastos perennes fueron mayores en la cercanía de pastos perennes que en el suelo desnudo o en las proximidades de subarbustos. El reclutamiento de pastos no difirió entre micrositios cuando la densidad de semillas no varió entre ellos o cuando las raíces de las plantas establecidas fueron excluidas. En cambio, el agua incrementó el reclutamiento de las plántulas de pastos perennes en todos los micrositios. En las áreas degradadas del Monte Patagónico la distribución espacial del banco de semillas y la disponibilidad de agua son, en ese orden, los principales factores limitantes del reclutamiento de plántulas de pastos perennes. Las prácticas de manejo tendientes a mantener y/o incrementar el banco de semillas de pastos perennes en el suelo, tales como la exclusión del pastoreo durante el periodo reproductivo de los pastos, podrían contribuir a promover el restablecimiento de los pastos perennes.

them (Garner and Steinberger 1989). Water concentration usually is the result of stemflow (Whitford et al. 1997), runoff from interpatch areas (Montaña et al. 1995), and/or hydraulic lift (Caldwell and Richards 1989). Senescence, and subsequent litterfall and decomposition account for the accumulation of organic matter and nutrients under plant patches (Jellman 1979). The concentration of seeds in the soil beneath or neighboring plant patches generally results from short seed-dispersal distances, characteristic of plants from arid-lands, and seed re-dispersal by wind or animals (Ellner and Shmida 1981). Plant patches also modify the microclimate in their neighborhood (Stoutjesdijk and Barkman 1992) creating sheltered areas where radiation, temperature, and evaporative demand may be lower relative to bare areas (Callaway 
1995). The accumulation of resources and the improvement of microclimatic conditions in the vicinity of established vegetation facilitate seedling establishment and other plant processes (Callaway and Pugnaire, 1999).

In the Patagonian Monte, overgrazing leads to the reduction of grass cover (Bisigato and Bertiller 1997), a decrease in the density of the soil seed bank of perennial grasses (Bisigato 2000), an increase of soil erosion (Parizek et al. 2002), shrub invasion (Bisigato and Bertiller 1997), and eventually to local plant extinction (Bisigato 2000). Intensive grazing also induces changes in the spatial heterogeneity of soil and plant resources affecting the availability of seeds and safe microsites for seedling establishment, and subsequently the potential for plant recovery (Bertiller et al. 2000, Bisigato 2000). These changes lead to the formation of bare-soil areas (diameter $>1 \mathrm{~m}$ ), which are frequently recolonized by the dwarf shrub tomillo macho [Junellia seriphioides (Gillies \& Hook.) Moldenke], and in some favorable situations by the perennial grass flechilla [Stipa tenuis Phil.] (Bisigato and Bertiller 1997).

Whether recolonization favors or inhibits the re-establishment of perennial grasses in disturbed areas is not clear. The hypotheses that incipient recolonization of large bare-soil areas by dwarf shrubs or perennial grasses creates favorable microsites for grass seedling recruitment, and that microsites neighboring dwarf shrubs or perennial grasses differ in their favorableness were tested. Dwarf shrubs provide higher sheltering and lower root competition in their neighborhood than do perennial grasses, and more seeds of perennial grasses are concentrated beneath their canopies than under dwarf shrubs or on bare soil. Under natural field conditions the recruitment of grasses was predicted to be greater next to established grasses than in the periphery of dwarf shrubs or in bare soil. When the density of seeds did not differ among microsites, the recruitment of seedlings of perennial grasses was predicted to be higher in the periphery of the established shrubs where more favorable micro-environmental conditions for grass seedling recruitment prevail relative to the other microsites.

\section{Materials and Methods}

\section{Study site}

The study site is located in north-eastern Patagonia (Argentina), $40 \mathrm{~km}$ west of
Puerto Madryn ( $42^{\circ} 39^{\prime} \mathrm{S}, 65^{\circ} 23^{\prime} \mathrm{W}, 115$ $\mathrm{m}$ a.s.l.). Annual mean temperature is 13.7 ${ }^{\circ} \mathrm{C}$ and average precipitation is $236 \mathrm{~mm}$ with high mean interannual variation (CENPAT 2001). Soils are a complex of Typic Petrocalcids-Typic Haplocalcids (del Valle 1998, Soil Survey Staff 1998). Vegetation is representative of the community of jarilla [Larrea divaricata Cav.] and flechillas Stipa spp., characteristic of the Patagonian Monte.

Vegetation covers 40 to $60 \%$ of the soil and has a random patchy structure consisting of large and diverse shrub-grass patches, and incipient small patches or isolated plants of shrubs or perennial grasses. Jarilla [Larrea divaricata], uña de gato [Chuquiraga hystrix D. Don], yaoyín [Lycium chilense Miers ex Bert.], molle [Schinus johnstonii F.A. Barkley], and zampa [Atriplex lampa Gill. ex Moq.] dominate the upper layer (1-2 m), while the lower layer $(<1 \mathrm{~m})$ is composed of perennial grasses (flechilla [Stipa tenuis], coirón amargo [S. speciosa Trin. \& Rupr.], coirón llama [S. humilis Cav.], and coirón poa [Poa ligularis Nees ex Steud.]) and dwarf shrubs (tomillo macho [Junellia seriphioides], Nassauvia fuegiana (Speg.) Cabrera, and tomillo [Acantholippia seriphioides (A. Gray) Moldenke]). Field measurements and experiments were conducted within 2.5 ha, excluded from sheep grazing since 1993 after more than 20 years of high sheep grazing pressure.

\section{Plant species}

Plants of tomillo macho (Junellia seriphioides) and flechilla (Stipa tenuis) located at the center of bare-soil areas (diameter $>1 \mathrm{~m}$ ) where sheltering of surrounding vegetation is of minor relevance were selected. Tomillo macho is a shallow-rooted dwarf shrub (< $1 \mathrm{~m}$ depth), $0.5-0.8 \mathrm{~m}$ in height, with spiny leaves and low annual leaf turnover, which increases in abundance in areas severely disturbed by grazing. Flechilla is a shallow rooted perennial grass (0.4-0.5 m depth), $0.15-0.40 \mathrm{~m}$ in height, with high annual leaf turnover and sensitivity to grazing (Correa 1988, Botta 1989, Bisigato and Bertiller 1997, Carrera et al. 2000).

\section{Precipitation}

During the period from January 1997 to December 1999, monthly precipitation was measured with an automatic datalogger (21X Micrologger, Campbell Scientific). For each year, the total and the autumn precipitation (91 days, from April 1 to June 30) were computed. The latter season is when perennial grasses germinate and emerge.

\section{Soil Moisture}

Soil moisture was assessed at approximately monthly intervals from June 1998 to October 1999 (14 dates). A completely randomized sampling design was used to extract 6 cylindrical soil cores $(4.8 \mathrm{~cm}$ diameter x $20 \mathrm{~cm}$ deep) at each of the following microsites: center of bare-soil areas $>1 \mathrm{~m}$ diameter (bare soil), isolated plants of tomillo macho and flechilla. Soil moisture was determined gravimetrically and expressed as water content per $100 \mathrm{~g}$ of dried soil ( $105^{\circ} \mathrm{C}$ for 48 hours). To highlight differences between microsites (independent from the seasonal variation), the relative soil moisture at each microsite was computed by deducting the overall average of soil moisture of each sampling date from the respective soil moisture value. The significance of the differences in untransformed relative soil moisture among microsites (tomillo macho, flechilla, and bare soil) was assessed by one way analysis of variance (ANOVA) (SPSS 1997). Before the analysis, ANOVA assumptions (normality, homoscedasticity, and independence of the errors) were tested (Sokal and Rohlf 1997).

\section{Root biomass}

In fall 2000 , root biomass was evaluated by extracting a cylindrical soil core (4.8 $\mathrm{cm}$ diameter and $20 \mathrm{~cm}$ depth) from 10 replicates of each microsite (tomillo macho, flechilla, and bare soil). The selection of soil cores was completely randomized. After extracting, roots were separated from the soil using a $0.5 \mathrm{~mm}$ mesh sieve, washed, dried at $45^{\circ} \mathrm{C}$ for 48 hours, and weighed (Rodriguez et al. 1995). Root biomass was expressed as $\mathrm{mg}$ of roots per $\mathrm{cm}^{3}$ of soil. The significance of the differences in untransformed root biomass among microsites (tomillo macho, flechilla, and bare soil) was assessed by analysis of variance (ANOVA) (SPSS, 1997). Before the analysis, ANOVA assumptions (normality, homoscedasticity, and independence of the errors) were tested (Sokal and Rohlf 1997).

\section{Germinable soil seed bank of peren- nial grasses}

In 1998 , immediately after seed rain (early autumn, Bertiller 1998), the density of the germinable soil seed bank of perennial grasses was evaluated by extracting completely randomized cylindrical soil cores ( $5 \mathrm{~cm}$ diameter, $2 \mathrm{~cm}$ depth) from 10 replicates of each microsite (tomillo macho, flechilla, and bare soil). After collection, the soil samples were wetted at field 
capacity, incubated for 6 months in laboratory conditions $\left(20^{\circ} \mathrm{C}\right)$ and stirred monthly. The emerged seedlings of perennial grasses were counted weekly and removed. The density of the seed bank (seeds $\mathrm{m}^{-2}$ ) at each microsite was estimated by the mean number of seedlings that emerged throughout the incubation period. The significance of the differences in the non-normally distributed density of the seed bank among microsites was tested by Mann-Whitney Test (SPSS 1997).

\section{Recruitment of perennial grasses \\ under natural field conditions}

Perennial grass recruitment was measured in a completely randomized sampling design. In July 1997 and September 1998 , all the seedlings of perennial grasses were counted in plots of $50 \times 50 \mathrm{~cm}$ centered at 10 isolated plants of tomillo macho, 10 of flechilla, and 10 large bare soil areas ( $>1 \mathrm{~m}$ diameter). Seedlings were considered perennial grass individuals with less than 3 tillers. Based on previous experience (Bertiller et al. 1996, Bisigato and Bertiller 1999, Bisigato 2000), this selection includes recently emerged to 2year old seedlings. The significance of the differences in seedling density among microsites (tomillo macho, flechilla, and bare soil) was evaluated by repeated measures analysis of variance (ANOVA) of the square root transformed values of seedling density. Data transformation was performed to improve normality. After transformation, ANOVA assumptions (normality, homoscedasticity, and independence of the errors) were newly tested (Sokal and Rohlf 1997).

\section{Recruitment of perennial grasses} under manipulated field conditions

Recruitment under manipulated field conditions was measured in a three factorial completely randomized experiment. In March 1999, 60 circular plots $(10 \mathrm{~cm}$ diameter) were installed: 20 beneath isolated plants of tomillo macho, 20 beneath flechilla, and 20 in bare soil. In 10 plots of each microsite, PVC tubes $(10 \mathrm{~cm}$ diameter, $20 \mathrm{~cm}$ deep) were buried to exclude root growth of the neighboring plants. In each plot (with and without PVC tubes), 10 scarified seeds of flechilla were buried to a depth of $1 \mathrm{~cm}$ to prevent seed predation. Half of the plots (5 with PVC tubes and 5 without PVC tubes) were watered with $20 \mathrm{~mm}$ of water per day during 10 days to ensure seedling emergence irrespective of climatic conditions. In September 1999, percentage of seedlings

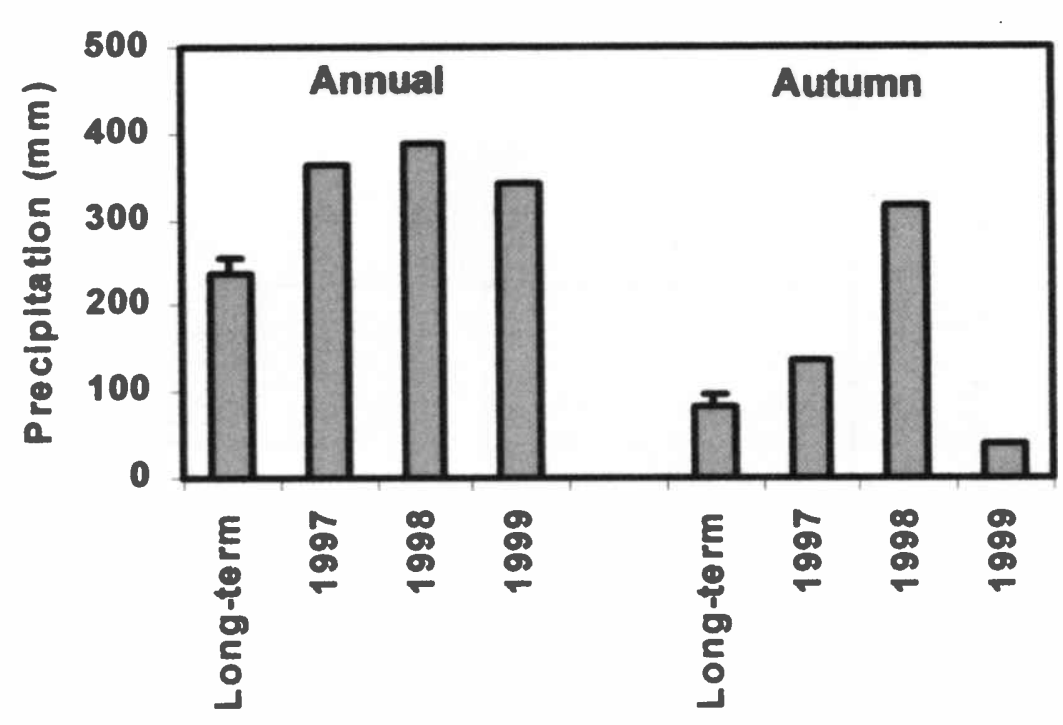

Fig. 1. Annual and autumn (April to June) precipitation for the study area. Vertical lines on long-term precipitation averages represent 1 standard error.

recruited from the seeds buried at each plot was calculated. Differences in mean (arcsin transformed) percentage seedling recruitment were tested using analysis of variance (ANOVA). Data were transformed to improve their normality and homoscedasticity. After transformation, ANOVA assumptions (normality, homo-scedasticity, and independence of the errors) were retested (Sokal and Rohlf 1997).

\section{Results}

\section{Environmental characteristics of microsites}

In the 3 years of the study, the annual precipitation was higher than the longterm average for the site. Autumn precipitation (April-June) was higher in 1997 and 1998, and lower in 1999 than the longterm average (Fig.1). The greatest soil moisture $(P<0.01)$ was found underneath plants of flechilla. In tomillo macho microsites, the relative soil moisture was significantly greater $(P<0.01)$ than in bare soil (Fig. 2a). Significant differences $(P=0.21)$ were not found in root biomass (0 to $20 \mathrm{~cm}$ ) among microsites (Fig. 2b). The germinable soil seed bank of grasses was greater $(P<0.05)$ in the vicinity of flechilla than next to tomillo macho plants and in bare soil (Fig. 2c).

\section{Recruitment of perennial grasses under natural and manipulated field conditions}

The recruitment of perennial grasses under natural conditions varied among microsites. It was higher $(\mathrm{P}<0.01)$ near flechilla than near tomillo macho or in bare soil, in both years (Fig. 3). Under manipulated field conditions, the number of seedlings of perennial grasses recruited 6 month from emergence did not differ significantly $(P=0.44)$ among microsites (Fig. 4). At all microsites, water addition increased $(\mathrm{P}<0.05)$ seedling densities while levels of root exclusion did not result in differences $(P=0.66)$ in seedling densities between them. There were no significant $(\mathrm{P}>0.05)$ effects of interactions among factors on seedling recruitment.

\section{Discussion}

Incipient recolonization of large baresoil areas by dwarf shrubs or perennial grasses had different effects on the underneath soil moisture (Fig. 2a), a fact probably related to the different aboveground architecture of the species representing each plant group. Flechilla exhibits a large and dense basal area which probably concentrates more water than the small and open basal area of tomillo macho (Correa 1988, Botta 1989). In contrast to findings in other studies (Soriano and Sala 1986, Breshears and Barnes 1999), root biomass in the upper $\mathrm{cm}$ of soil $(0-20 \mathrm{~cm})$ did not differ among microsites (Fig. 2b). The greater concentration of seeds of perennial grasses found in the neighborhood of flechilla relative to microsites adjacent to tomillo macho or on bare soil (Fig. 2c) is consistent with the prevalence of shortrange seed dispersal (Ellner and Shmida 1981, Cheplick 1998), and heterogeneous 

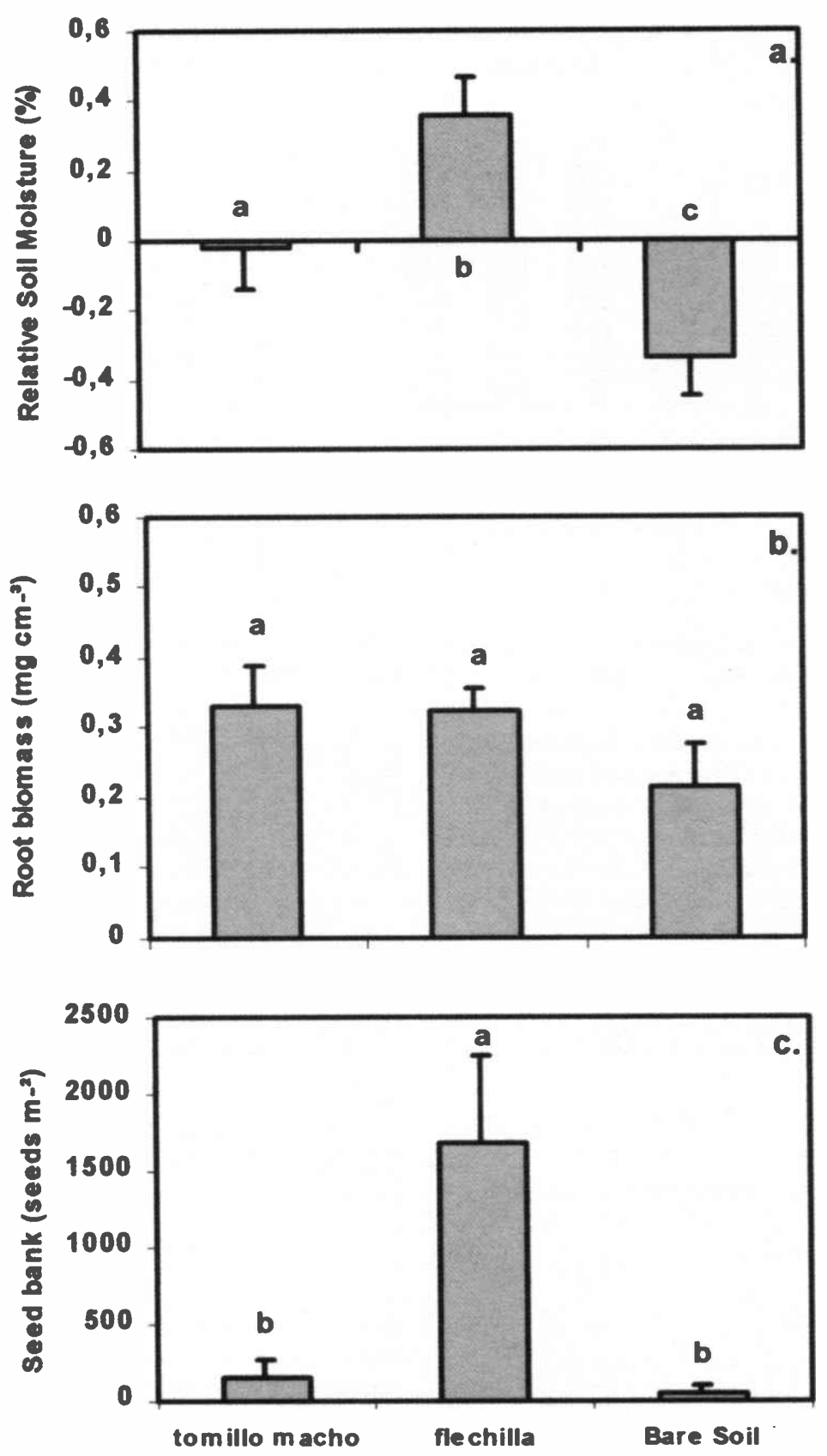

Fig. 2. Relative soil moisture (a), root biomass (b), and seed bank density (c) by microsite (means $\pm \mathrm{SE})$. Different lowercase letters indicate significant $(P<0.05)$ differences among microsites.

spatial patterns of seeds in soil (Kemp 1989, Eriksson and Ehrlén 1992, Guo et al., 1998) reported for plants of arid ecosystems, including the Patagonian Monte (Bertiller 1998).

As predicted, under natural field conditions, greater seed availability (Fig. 2c) and soil moisture associated with established perennial grasses (Fig. 2a) promoted greater seedling recruitment of perennial grasses compared to microsites on bare direct or indirect effects of established vegetation on early stages of grass seedling development ( $0^{\prime}$ Connor 1996, Defossé et al. 1997). Other studies, however, found negative or positive effects of established plants on seedling establishment and plant processes. Some indicated root competition was an important limiting factor for plant growth and seedling establishment (Aguiar et al. 1992, Aguilera and Lauenroth 1993, Lauenroth and Aguilera 1998). Others found evidence of facilitation of grass seedling recruitment by established plants (Pugnaire et al. 1996, Moro et al. 1997, Callaway and Pugnaire 1999).

This variation in the relationships between seedlings and established plants (neutral, competitive, or facilitative) has been associated with intra- and inter-annual climatic variability (Greenlee and Callaway 1996, Callaway and Pugnaire 1999). The lack of significant effects of microsite or its interactions on seedling recruitment in our manipulative experiment could indicate that biotic interactions (such as facilitation or competition) between isolated dwarf shrubs or perennial grasses and perennial grass seedlings are weak. Small plant patches or isolated plants could have weaker effects on seedling establishment than large plant patches as reported for other arid ecosystems (Facelli and Brock 2000, Pugnaire and Lázaro 2000). Biotic interactions, however, might be dampened by other influences in a single year manipulative experiment in which autumn precipitation was lower than the long term mean.

The promotion of recruitment of grass seedlings at all microsites by water addition (Fig. 4) could be related to the extremely low autumn precipitation in the year when the manipulative experiment was carried out (Fig. 1). In many desert communities, the recruitment of grasses depends on the occurrence of above-average rain events (Lauenroth et al. 1994). Particularly, the recruitment and/or growth of flechilla in the Patagonian Monte are strongly coupled with water inputs (Distel and Fernández 1987, Bertiller et al. 1991, Becker et al. 1997). Similar results were also found in other arid ecosystems of Patagonia where water stress reduced the growth and establishment of grass seedlings (Bertiller et al. 1996, Defossé et al. 1997).

Results from this study are relevant in the context of the maintenance of plant patch structure and dynamics. Heavy grazing leads to strong reductions in the soil seed bank of perennial grasses by the 

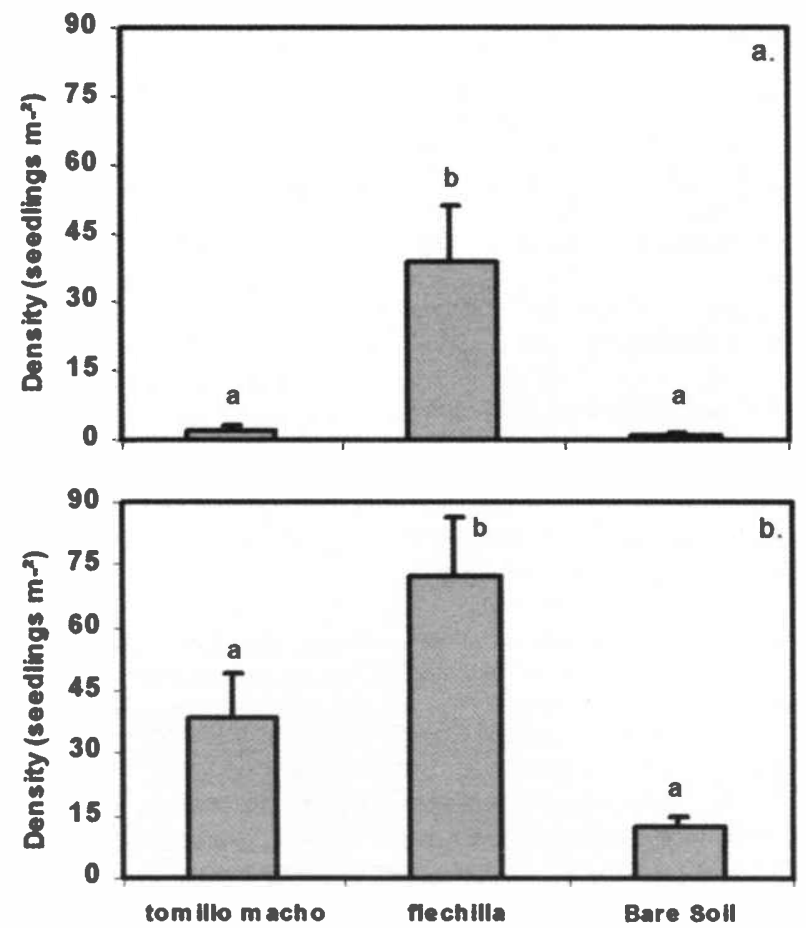

Fig. 3. Seedling density of perennial grasses (natural field conditions) by microsite in 1997 (a) and 1998 (b) (means \pm SE). Different lowercase letters indicate significant $(P<0.05)$ differences among microsites within each year.
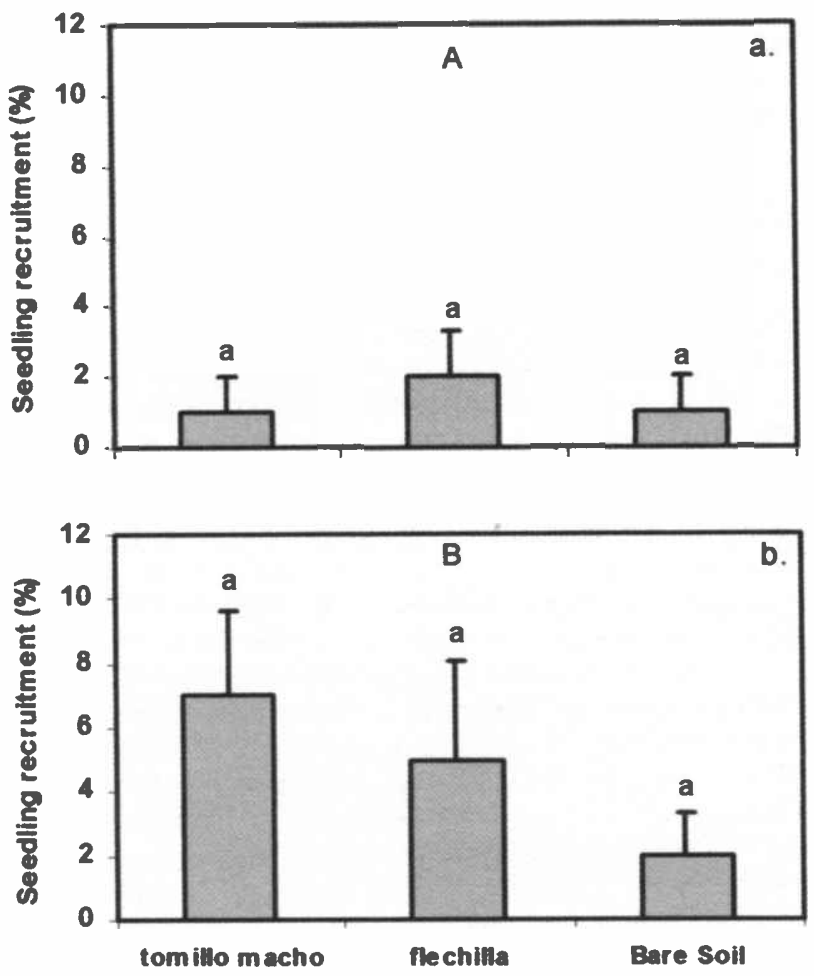

Fig. 4. Seedling recruitment (mean $\pm \mathrm{SE}$ ) of Stipa tenuis (manipulative field experiment) by microsite and water addition level (without water addition (a), with water addition (b)). Results on different root-exclusion levels were grouped for data presentation (not significant effect of root-exclusion on seedling recruitment). Different lowercase letters indicate significant $(P<0.05)$ differences among microsites within each water addition level, and different uppercase letters indicate significant $(P<0.05)$ differences between water addition levels. reduction of the grass cover and the removal of grass reproductive tissues (Bertiller and Coronato 1994, Navie et al. 1996, Witkowski and Garner 2000). For the study area, Bisigato (2000) also reported reductions in the soil seed bank of perennial grasses following grazing. Since perennial grasses show transient soil seed banks (O'Connor 1991, Bertiller and Aloia 1997), a succession of dry years in grazed areas with restricted seed rain could deplete the soil seed bank of perennial grasses leading, in extreme conditions, to the local extinction of grass patches as reported for other arid ecosystems (Hunt 2001). Managerial practices oriented to maintain and increase the soil seed bank of perennial grasses, such as grazing exclusion during the grass reproductive period, might contribute to promote the re-establishment of perennial grasses and the maintenance and expanding of grass patches.

\section{Conclusion}

These results allowed identification of hierarchical controls of seedling recruitment in large degraded areas of the Patagonian Monte. Under natural field conditions, seeds and seedlings were concentrated near perennial grasses. When the soil seed bank of perennial grasses was homogeneously distributed, seedling recruitment did not vary among microsites. Consequently, the main limiting factor to seedling recruitment of grasses can be inferred as the heterogeneous spatial distribution of the soil seed bank.

\section{Literature Cited}

Aguiar, M.R., A. Soriano, and O.E. Sala. 1992. Competition and facilitation in the recruitment of seedlings in a Patagonian steppe. Funct. Ecol. 6:66-70.

Aguilera, M.O. and W.K. Lauenroth. 1993. Seedling establishment in adult neighbourhoods - intraespecific constraints in the regeneration of the bunchgrass Bouteloua gracilis. J. Ecol. 81:253-261.

Becker, G.F., C.A. Busso, T. Montani, A.L. Orchansky, R.E. Brevedan, M.A. Burgos, and A.C. Flemmer, 1997. Effects of defoliating Stipa tenuis and Piptochaetium napostaense at different phenological stages: tiller demography and growth. J. Arid Environ. 35:251-268.

Bertiller, M.B. 1998. Spatial patterns of the germinable soil seed bank in northern Patagonia. Seed Sci. Res. 8:39-45.

Bertiller, M.B. and D.A. Aloia. 1997. Seed bank strategies in Patagonian semi-arid 
grasslands in relation to their management and conservation. Biodivers. Conserv. 6:639-650.

Bertiller, M.B. and F. Coronato. 1994. Seed bank patterns of Festuca pallescens in semiarid Patagonia (Argentina): a possible limit to bunch reestablishment. Biodivers. Conserv. 3:57-67.

Bertiller, M.B., A.M. Beeskow, and F. Coronato. 1991. Seasonal environmental variation and plant phenology in arid Patagonia (Argentina). J. Arid Environ. 21:1-11.

Bertiller, M.B., J.O. Ares, P. Graff, and R. Baldi. 2000. Sex-related spatial patterns of Poa ligularis in relation to shrub patch occurrence in northern Patagonia. J. Veg. Sci. 11:9-14.

Bertiller, M.B., P. Zaixso, MdelP. Irisarri, and E.R. Brevedan. 1996. The establishment of Festuca pallescens in arid grasslands in Patagonia (Argentina): the effect of soil water stress. J. Arid Environ. 32:161-171.

Bisigato, A.J. 2000. Dinámica de la vegetación en áreas pastoreadas del extremo austral de la Provincia Fitogeográfica del Monte. PhD Thesis. University of Buenos Aires. Buenos Aires.

Bisigato, A.J. and M.B. Bertiller. 1997. Grazing effects on patchy dryland vegetation in northern Patagonia. J. Arid Environ. $36: 639-653$.

Bisigato, A.J. and M.B. Bertiller. 1999. Seedling emergence and survival in contrasting soil microsites in Patagonian Monte shrubland. J. Veg. Sci. 10:335-342.

Botta, S.M. 1989. Estudios en el género sudamericano Junellia (Verbenaceae, Verbenoideae) I. Delimitación y tratamiento infragénico. Darwiniana 29:371-396.

Breshears, D.D. and F.J. Barnes. 1999. Interrelationships between plant functional types and soil moisture heterogeneity for semiarid landscapes within the grass/forest continuum: a unified conceptual model. Landscape Ecol. 14:465-478.

Caldwell, M.M. and J.H. Richards. 1989. Hydraulic lift: water efflux from upper roots improves effectiveness of water uptake by deep roots. Oecologia 79:1-5.

Callaway, R.M. 1995. Positive interactions among plants. Bot. Rev. 61:306-349.

Callaway, R.M. and F.I. Pugnaire. 1999. Facilitation in plant communities, p 623-648. In: Pugnaire, F.I., and F. Valladares. (eds) Handbook of functional plant ecology. Marcel Dekker, New York.

Carrera, A.L., C.L. Sain, and M.B. Bertiller. 2000. Patterns of Nitrogen conservation in shrubs and grasses in the Patagonian Monte, Argentina. Plant Soil 224:185-193.

CENPAT 2001. Estación meteorológica, área de física ambiental. CENPAT-CONICET. "http://www.centropatagonico.com".

Cheplick, G.P. 1998. Seed dispersal and seedling establishment in grass populations, p. 84-105. In: Cheplick, G.P. (ed.) Population biology of grasses. Cambridge University Press, Cambridge.
Correa, M.N. 1988. Flora patagónica. Colección científica. Instituto Nacional de Tecnología Agropecuaria (INTA), Buenos Aires.

Defossé, G.E., M.B. Bertiller, and R. Robberecht. 1997. Effects of topography, soil moisture, wind and grazing on Festuca seedlings in a Patagonian grassland. J. Veg. Sci. 8:677-684.

del Valle, H.F. 1998. Patagonian soils: a regional synthesis. Ecología Austral 8:103-123.

Distel, R.A. and O.A. Fernández. 1987. Leaf water potential trends in three grasses native to semiarid Argentina. J. Range Manage. 40:203-207.

Ellner, S. and A. Shmida. 1981. Why are adaptations for long-range seed dispersal rare in desert plants? Oecologia 51:133-144.

Eriksson, O. and J. Ehrlén. 1992. Seed and microsite limitation of recruitment in plant populations. Oecologia 91:360-364.

Facelli, J.M. and D.J. Brock. 2000. Patch dynamics in arid lands: localized effects of Acacia papyrocarpa on soils and vegetation of open woodlands of south Australia. Ecography 23:479-491.

Garner, W. and Y. Steinberger. 1989. A proposed mechanism for the formation of "Fertile Islands" in the desert ecosystem. J. Arid Environ. 16:257-262.

Greenlee, J.T. and R.M. Callaway. 1996. Abiotic stress and the relative importance of interference and facilitation in montane bunchgrass communities in western Montana. Amer. Nat. 148:386-396.

Guo, Q., P.W. Rundel, and D.W. Goodall. 1998. Horizontal and vertical distribution of desert seed banks: patterns, causes, and implications. J. Arid Environ. 38:465-478.

Hunt, L.P. 2001. Heterogeneous grazing causes local extinction of edible perennial shrubs: a matrix analysis. J. Appl. Ecol. 38:238-252.

Jellman, M. 1979. Soil enrichment by neotropical savanna trees. J. Ecol. 67:565-577.

Kemp, P.R. 1989. Seed banks and vegetation processes in deserts, p. 257-281. In: Leck, M.A., V.T. Parker, and R.L. Simpson. (eds.) Ecology of Seed Banks. Harcourt Brace Jovanovich, San Diego, Calif.

Lauenroth, W.K. and M.O. Aguilera. 1998. Plant-plant interactions in grasses and grasslands, p. 209-230. In: Cheplick, G.P. (ed.), Population biology of grasses. Cambridge University Press, Cambridge.

Lauenroth, W.K., O.E. Sala, D.P. Coffin, and T.B. Kirchner. 1994. Recruitment of Bouteloua gracilis in the shortgrass steppe: a simulation analysis of the role of soil water. Ecol. Appl. 4:741-749.

Montaña, C., B. Cavagnaro, and O. Briones. 1995. Soil water use by co-existing shrubs and grasses in the southern Chihuahuan desert, Mexico. J. Arid Environ. 31:1-13.

Moro, M.J., F.I. Pugnaire, P. Haase, and J. Puigdefábregas. 1997. Mechanisms of interaction between a leguminous shrub and its understorey in a semiarid environment. Ecography 20:175-184.
Navie, S.C., R.A. Cowley, and R.W. Rogers. 1996. The relationship between distance from water and the soil seed bank in a grazed semi-arid subtropical rangeland. Aust. J. Bot. 44:421-431.

Noy-Meir, I. 1973. Desert ecosystems: environment and producers. Annu. Rev. Ecol. Syst. 4:25-52.

O'Connor, T.G. 1991. Local extinction in perennial grasslands: a life-history approach. Am. Nat. 137:753-773.

O'Connor, T.G. 1996. Hierarchical control over seedling recruitment of the bunch-grass Themeda triandra in a semiarid savanna. J. Appl. Ecol. 33:1094-1 106.

Parizek, B., C.M. Rostagno, and R. Sotini. 2002. Soil erosion as affected by shrub encroachment in north-eastern Patagonia. J. Range Manage. 55:43-48.

Pugnaire, F.I. and R. Lázaro. 2000. Seed bank and understorey species composition in a semi-arid environment: the effect of shrub age and rainfall. Ann. Bot-London 86:807-813.

Pugnaire, F.I., P. Haase, and J. Puigdefábregas. 1996. Facilitation between higher plant species in a semiarid environment. Ecology 77:1420-1426.

Rodriguez, M.A., V.K. Brown, and A. Gómez-Sal. 1995. The vertical distribution of below-ground biomass in grassland communities in relation to grazing regime and habitat characteristics. J. Veg. Sci. 6:63-72.

Ryser, P. 1993. Influences of neighbouring plants on seedling establishment in limestone grassland. J. Veg. Sci. 4:195-202.

Sokal, R.R. and F.J. Rohlf. 1997. Biometry. Freeman and Company, New York.

Soil Survey Staff. 1998. National soils handbook. USDA-NRCS, Washington D.C.

Soriano, A. and O.E. Sala. 1986. Emergence and survival of Bromus setifolius seedlings in different microsites of a Patagonian arid steppe. Israel J. Bot. 35:91-100.

SPSS. 1997. SPSS Advanced Statistics ${ }^{\mathrm{TM}} 7.5$. United States of America.

Stoutjesdijk, P. and J.J. Barkman. 1992. Microclimate, vegetation and fauna. Opulus Press, Knivsta, Sweden.

Whitford, W.G., J. Anderson, and P.M. Rice. 1997. Stemflow contribution to the 'fertile island' effect in creosotebush, Larrea tridentata. J. Arid Environ. 35: 451-457.

Witkowski, E.T.F. and R.D. Garner. 2000. Spatial distribution of soil seed banks of three African savanna woody species at two contrasting sites. Plant Ecol. 149:91-106. 